\title{
Research on the Governance Structure and Corporate Performance of Listed Companies--Based on the Internal and External Governance Structure of the Company
}

\author{
Xue-Xia Xu,Ming-Zhi Zhang",Hao-Yu Zhang,Si-Min Guo \\ College of Accounting, Wuhan Textile University, Wuhan, 430200, China \\ Email: mingzhizhang66@163.com
}

\begin{abstract}
In this paper, the Shanghai A-share listed companies' annual reports of three consecutive years from 2012 to 2014 were used as the research samples. through the establishment of regression model, the empirical analysis have been done with the influences of the internal governance structure and external governance structure of listed companies to corporate performance. Hope that through the comprehensive study of internal and external variables, in order to provide data support to the listing Corporation governance structure. The results showed that the proportion of independent directors, executive incentives, institutional investors and other governance structure variables were significantly positively related to corporate performance, and also creditor governance had a significant negative correlation with corporate performance.
\end{abstract}

Keywords-listed company, corporate governance structure, corporate performance

\section{INTRODUCTION}

In China, with the establishment of the modern enterprise system, people gradually realize that the corporate governance structure is the decisive function to the performance and competitiveness of enterprises. The supervision to shareholders and control of high-level decision-making and behavior will affect the company's strategic plan, eventually will directly affect the performance of the company, namely corporate governance structure on corporate performance play very important role.

In the academic field, the research literature on corporate governance structure and corporate performance is abundant. Foreign scholars' research on the governance structure and performance of listed company has started earlier, and has achieved fruitful results. Fama and Jensen (1983), KeaseROE(1993) believes that the corporate governance structure is to solve the relationship between owners and operators, this is a mechanism that make them have the same interests[1,2]. Domestic academic research on corporate governance structure and corporate performance is relatively late, and the conclusion of this research is mainly reflected in the following: the structure of corporate governance, such as equity concentration (Dang Xiaolan, 2013) [3], independent director proportion (Li Qing, 2014)[4] and corporate performance is positive correlation.

Literature review showed that the corporate governance structure involved a lot of variables, but only the board characteristics, ownership structure, the board of supervisors and executive incentive were broadly applied. But for the external governance of listed company, the empirical research is relatively less. This article focuses on how internal and external variables in the study affect the company's performance.

\section{THEORETICAL ANALYSIS AND RESEARCH HYPOTHESIS}

\section{A. Ownership Structure and Corporate Performance}

Ownership structure including Ownership concentration and Equity restriction, When the proportion of the largest shareholder holding more than $40 \%$, its stake positively correlated with corporate performance (Li Weian,2006) [5]. Chen Xinyuan (2004) thinks that a company with an equity based confrontation, The Tobin $\mathrm{Q}$ value and $\mathrm{PB}$ value are higher than the other listed companies [6]. This shows that equity confrontation has a significant role in improving the performance of the company, Therefore, so we put forward the following hypothesis:

Hypothesis 1: under other conditions, ownership concentration and corporate performance exist positive relationship.

Hypothesis 2: under other conditions, Equity restriction and corporate performance exist positive relationship.

\section{B. Board and Corporate Performance}

Board including board size and independent directors, One view is that the board with small-scale will help improve corporate performance; Chen Mei (2011) believed that there were a significant positive correlation between the independent directors and corporate performance ${ }^{[7]}$.thus, we propose the following hypothesis:

Hypothesis 3: under other conditions, The board size and the firm performance are nonlinear

Hypothesis 4: under other conditions, independent directors size and corporate performance exist positive relationship.

\section{Board of Supervisors and Corporate Performance}

In theory, if the supervisory board participating in governance will enhance the performance of the company [8].Therefore, the following assumptions are proposed:

Hypothesis5: under other conditions, the scale of the board of supervisors and corporate performance exist 
positive relationship.

\section{Managers and Corporate Performance}

Wang Zhe, Wang Hao (2011) believed that there was a significant positive correlation between executive incentive and corporate performance [9]. therefore the following assumptions were presented in this paper:

Hypothesis 6: under other conditions, CEO salary and corporate performance exist positive relationship.

\section{E. External Governance and Corporate Performance}

\section{Creditor Governance and Corporate Performance}

Incentive theory thinks that creditors incentives are more effective for managers than the owners, Therefore, the following assumptions were proposed:

Hypothesis 7: under other conditions, creditor governance and corporate performance exist positive relationship.

\section{F. Institutional Investors and Corporate Performance}

Due to institutional investors are more willing to invest the listed company with higher governance efficiency, Virtually can put pressure on the managers, so put forward the following hypothesis:

Hypothesis 8: under other conditions, institutional investors governance and corporate performance exist positive relationship.

\section{G. Supplier Governance and Corporate Performance}

Supplier and enterprise as the upstream and downstream of the supply chain respectively, can produce external supervision and restriction to corporate governance. therefore the following hypothesis were put forward:

Hypothesis 9: under other conditions, supplier governance and corporate performance exist positive relationship.

\section{RESEARCH DESIGN}

\section{A. Sample Selection and Data Sources}

This study used the Shanghai A shares of listed companies as samples, and executed the following screening procedures: (1) excluding ST and * ST companies, the main consideration was that extreme financial data of ST and * ST companies would affect the credibility of the test results. (2) Excluding the companies with incomplete data related indicators in 2012--2014 for three consecutive years. (3) Excluding financial listed companies. Finally 751 valid samples of the companies combined with 2176 observations were obtained. In this paper, all financial data were from Choice terminal database and completed by hand finishing.

\section{B. Selection and Description of Variables}

\section{Model Design}

In order to test the hypothesis proposed in this paper, we constructed the following basic measurement model:

$\mathrm{EPS}=\beta 0+\beta 1 * \mathrm{HER}+\beta 2 * \mathrm{~K}+\beta 3 * \mathrm{BSS}+$ $\beta 4 * \mathrm{IND}+\beta 5 * \mathrm{PSS}+\beta 6 * \mathrm{SAL}+\beta 7 * \mathrm{CG}+\beta 8 * \mathrm{IIG} \beta 9 * \mathrm{SG}+\beta 10 * \mathrm{Z}$ $+\varepsilon$

\section{EMPIRICAL ANALYSIS}

\section{Descriptive Analysis}

The data in the table 2 showed the mean and standard deviation of EPS is $0.3204,0.6799$. they verified the volatility of the economy. Initially, we conclude:

The HER and IND were generally able to exert significant influence on company decisions, the $\mathrm{CG}$ was 0.5153 , which meant relatively higher overall debt level of the listed companies. The maximum and minimum of SG was 526.5253, 0.0298. The main reason for this enormous discrete effect was that most listed companies have different natures in their main businesses, and also with different liquidity demands.

\section{Correlation Analysis}

From the table 3 we can see: the HER, IND, SAL, IIG and EPS was significant positive correlation, initially confirmed the hypothesis 1 , hypothesis 4 , hypothesis 6 and hypothesis 8.CG and EPS was a significant negative correlation.

\section{E. Regression Analysis}

After correlation analysis having been done, we could basically determine the relationship between variables. But we needed to do further tests, namely regression analysis.

From the table 4 regression analysis table, we come to the conclusion:

From the internal governance structure, the correlation coefficient between IND, SAL and EPS is 0.841. 0.489.and significantly strong, it confirmed the hypothesis 4, hypothesis 6 . from the external governance structure, the correlation coefficient between IIG and EPS is 0.196. and significantly strong, it confirmed the hypothesis 8 . the asset liability ratio had a significant negative correlation with the performance of the company, which was contrary to the hypothesis 7 .

\section{SUGGESTION}

In view of the above conclusions, we put forward the following suggestions: Firstly, listed companies should improve the corporate governance structure, such as increasing the proportion of independent directors, and to control the size of the board. While listed companies should adopt certain incentives for the executive team to play a greater initiative of management. Secondly, pay attention to their financial situation, and to avoid excessive debt management. Finally, improve their visibility, so that to attract more institutional investors to join in.

\section{REFERENCES}

[1] Fama .E,M .Jensen. Separation of Ownership and Control [J].Law and Economics, 1983, (26): 17-23.

[2] KeaseEPS .K ,M .Wright. Issues in Corporate AccountabilitEPS and 
Governance: AN Editorial [J].Accounting and Business Research, 1993, (23): 35-39.

[3]Dang Xiaolan, Li Xuejun, Wu Nian. Research on the governance structure and corporate performance of listing Corporation [J]. Accounting Communications, 2013, (9): 34-36.

[4]Li Qing. The impact of corporate governance on Corporate Performance -- Based on the data of GEM Listing Corporation [J]. Accounting Communications, 2014, (5): 19-21.

[5] Li Weian, Hao Chen. Chinese Listed Companies Empirical Research of Supervisory Board Governance [J]. Journal Of Shanghai University of Finance and Economics, 2006, (3): 79-81.

[6] Chen Xinyuan. Equity balance and corporate value: model and empirical evidence [J]. Quantitative Economic And Technological Economics Research, 2004, (11): 106-108

[7] Chen Mei. The influence of the board structure of listing Corporation on Corporate Performance -- An Empirical Study on the data of listing Corporation in the information technology industry in China [J]. Friends of Accounting, 2011, (19): 76-78.

[8] Guo Chunlin. Empirical research on the relationship between corporate governance structure and firm performance [J]. Chinese Management Information, 2015, (9): 100-102.

[9] Wang Zhe, Wang Hao relationship between executives of listed companies and the Company Performance [J] Guangdong Agricultural Sciences, 2011 (15): 218-219.

TABLE I. DESCRIPTION OF VARIABLES

\begin{tabular}{|c|c|c|c|}
\hline & Variable name & symbol & Variable Description \\
\hline $\begin{array}{l}\text { Explained } \\
\text { variable }\end{array}$ & corporate performance & EPS & Earnings per share as a measure of corporate performance \\
\hline \multirow{9}{*}{$\begin{array}{l}\text { Explanatory } \\
\text { variables }\end{array}$} & Share Concentratio & HER & The proportion of the first largest shareholder \\
\hline & Equity balance degree & K & $\begin{array}{l}\text { Ratio ranked the second, the third shareholders holding the combined } \\
\text { proportion of the total is divided by shareholder }\end{array}$ \\
\hline & Board Size & BSS & The total number of personnel of the Board \\
\hline & $\begin{array}{l}\text { Proportion of independent } \\
\text { directors }\end{array}$ & IND & Proportion of independent directors in the board of directors \\
\hline & $\begin{array}{c}\text { The size of the Supervisory } \\
\text { Board }\end{array}$ & PSS & Number of board of supervisors \\
\hline & Executive Pay & SAL & $\begin{array}{c}\text { The common logarithm of the sum of the previous three senior management } \\
\text { personnel }\end{array}$ \\
\hline & Creditor governance & CG & Liability-assets Ratio \\
\hline & $\begin{array}{c}\text { Institutional investors } \\
\text { governance }\end{array}$ & IIG & The proportion of IIG in the top ten shareholders \\
\hline & Supplier management & SG & Accounts payable turnover rate \\
\hline $\begin{array}{l}\text { Control } \\
\text { variable }\end{array}$ & Total assets & A & The total assets take the common logarithm \\
\hline
\end{tabular}


TABLE II. .DESCRIPTIVE STATISTICS OF ALL SAMPLE VARIABLES

\begin{tabular}{|c|c|c|c|c|c|c|}
\hline Variable name & symbol & sample size & Minimum & maximum & mean & $\begin{array}{c}\text { standard } \\
\text { deviation }\end{array}$ \\
\hline Company performance & EPS & 2176 & -3.0025 & 14.5800 & 0.3204 & 0.6799 \\
\hline $\begin{array}{c}\text { Share Concentrate } \\
\text { ratio }\end{array}$ & HER & 2176 & 0.0220 & 0.8855 & 0.3730 & 0.1640 \\
\hline Equity balance degree & K & 2176 & 0.0018 & 1.9604 & 0.3729 & 0.3984 \\
\hline Board Size & BSS & 2176 & 4 & 17 & 8.8900 & 1.9370 \\
\hline $\begin{array}{c}\text { Proportion of } \\
\text { independent directors }\end{array}$ & IND & 2176 & 0.2222 & 0.8333 & 0.3788 & 0.0676 \\
\hline $\begin{array}{c}\text { The size of the } \\
\text { Supervisory Board }\end{array}$ & PSS & 2176 & 1 & 8 & 2.38 & 0.8230 \\
\hline Executive Pay & SAL & 2176 & 4.8692 & 7.4457 & 6.1494 & 0.3048 \\
\hline Creditor governance & CG & 2176 & 0.0351 & 0.9550 & 0.5153 & 0.2020 \\
\hline $\begin{array}{c}\text { Institutional investors } \\
\text { governance }\end{array}$ & IIG & 2176 & 0.0001 & 0.9194 & 0.4300 & 0.2166 \\
\hline Supplier management & SG & 2176 & 0.0298 & 526.5253 & 9.5770 & 20.1180 \\
\hline company size & SIZE & 2176 & 7.7646 & 12.3812 & 9.7307 & 0.5920 \\
\hline Equity multiplier & EM & 2176 & 1.0364 & 22.2227 & 2.6713 & 1.9160 \\
\hline
\end{tabular}

TABLE III. CORRELATION ANALYSIS OF VARIABLES AND PERFORMANCE

\begin{tabular}{|c|c|c|c|c|c|c|c|c|c|c|c|}
\hline & EPS & HER & $\mathrm{K}$ & BSS & IND & PSS & SAL & CG & IIG & SG & $\mathrm{Z}$ \\
\hline EPS & 1.000 & & & & & & & & & & \\
\hline HER & 0.115 *** & 1.000 & & & & & & & & & \\
\hline K & -0.006 & $\begin{array}{l}-0.581 \\
* * *\end{array}$ & 1.000 & & & & & & & & \\
\hline BSS & -0.014 & 0.016 & 0.009 & 1.000 & & & & & & & \\
\hline IND & $0.129 * * *$ & $\begin{array}{l}0.054 * \\
*\end{array}$ & $0.053^{* *}$ & $-0.067 * *$ & 1.000 & & & & & & \\
\hline PSS & 0.024 & $\begin{array}{l}0.102 * \\
*\end{array}$ & $-0.067 * *$ & $0.234 * * *$ & 0.087 *** & 1.000 & & & & & \\
\hline SAL & $0.296 * * *$ & $\begin{array}{l}0.130^{*} \\
* *\end{array}$ & $0.069^{* * *}$ & $0.087 * * *$ & $0.053^{* *}$ & 0.098 *** & 1.000 & & & & \\
\hline CG & $-1.43 * * *$ & 0.034 & -0.027 & $0.078 * * *$ & $0.098 * * *$ & $0.107 * * *$ & $0.041^{*}$ & 1.000 & & & \\
\hline IIG & $0.135^{* * * *}$ & $\begin{array}{l}0.432 * \\
* *\end{array}$ & $-0.182^{* * * *}$ & $0.109 * * *$ & 0.038 & $0.172^{* * * *}$ & $0.197 * * *$ & $0.129 * * *$ & 1.000 & & \\
\hline SG & -0.014 & -0.002 & $-0.051 * *$ & 0.008 & -0.013 & 0.016 & -0.010 & -0.020 & -0.03 & 1.000 & \\
\hline $\mathrm{Z}$ & $0.215^{* * *}$ & $\begin{array}{l}0.382 * \\
* *\end{array}$ & $-0.092 * * *$ & $0.180 * * *$ & $0.154 * * *$ & $0.224 * * *$ & $0.441^{* * * *}$ & $\begin{array}{l}0.0345^{* *} \\
*\end{array}$ & $\begin{array}{l}0.351^{*} \\
*\end{array}$ & $-0.063 * *$ & $\begin{array}{l}1.00 \\
0\end{array}$ \\
\hline
\end{tabular}

Note: $* \mathrm{p}<0.1, \quad * * \mathrm{p}<0.05, \quad * * * \mathrm{p}<0.01$ 
TABLE IV. REGRESSION ANALYSIS

\begin{tabular}{|c|c|c|c|c|c|c|c|c|c|c|}
\hline Model & HER & $\mathrm{K}$ & BSS & IND & PSS & SAL & CG & IIG & SG & $\mathrm{Z}$ \\
\hline \multirow{2}{*}{ B } & -0.011 & -0.012 & -0.006 & 0.841 *** & -0.011 & $0.489 * * *$ & $-0.722 * * *$ & $0.196 * * *$ & $-9.082 \mathrm{E}-5$ & $0.188^{* * * *}$ \\
\hline & $(-0.095)$ & $(-0.283)$ & $(-0.713)$ & (3.726) & $(-0.649)$ & (9.732) & $(-9.935)$ & (2.740) & $(-0.135)$ & (6.023) \\
\hline $\mathrm{F}$ & \multicolumn{2}{|c|}{$38.176 * * *$} & \multicolumn{2}{|c|}{$\mathrm{R}^{2}$} & \multicolumn{2}{|c|}{0.150} & \multicolumn{2}{|c|}{ Adjusted $\mathrm{R}^{2}$} & \multicolumn{2}{|c|}{0.146} \\
\hline te: T-test v & kets & & & & & & & & & \\
\hline
\end{tabular}

